Historic, Archive Document

Do not assume content reflects current scientific knowledge, policies, or practices. 

NEW, RARE BEAUTIFUL

\section{PLANTS, SEEDS BUURS}

OFFERED, RAISED, OR

INTRODUCED BY
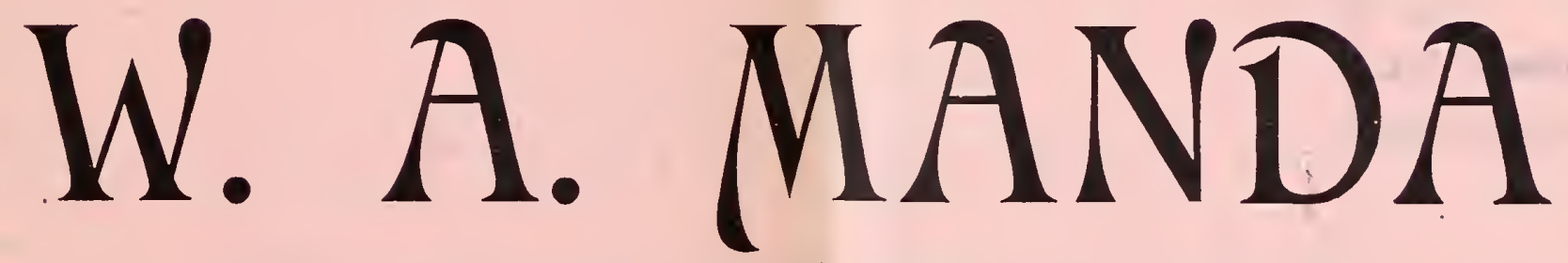

South Orange, N. J.

\section{New Roses,}

New Phlox,

New Carnations,

New Caladiums,

5.5. New Chrysanthemums,

New Callas,

New Cannas,

AND MANY OTHER WELL TRIED * * *

NOVELTIES OF STERLING MERIT,

All Superior to Present Existing Varieties. GIVE THEM a G00D TRIAL. 


\title{
NOVELTIES IN FLOWER SEEDS.
}

\section{MANDA'S IMPROVED GOLDEN-LEAVED SALVIA}

\author{
(SEED.)
}

$\Gamma$ HIS is without doubt the finest introduction made amongst our popular plants for years past, for in this plant we have a contrast of color between the foliage and flowers which is simply marvelous, thus giving it a unique position as a foliage and flowering plant. It grows about one foot and a half high, and is far more dwarf and compact in its habits than William Bedman. Seeing it from a short distance, one would take it for the wellknown Golden Bedder Coleus, except for the masses of brilliant scarlet-flowered spikes which loom up over the yellow foliage. The effect produced when this gem is planted en masse on a lawn is extremely fine. The contrast between the golden yellow foliage, the scarlet flowers, and the green grass gives to us the grandest combination of colors imaginable. The color of the leaves is constant and distinct at any stage of the plant inside or out of doors.

This novelty comes true from seed and may bring out new types. Price, per packet, 25 cents.

\section{MANDA'S HYBRID CANNAS.}

From the very finest varieties only, and sure to produce some extraordinary varieties. Per packet, 25 cents.

\section{CALLIOPSIS LANCEOLATA GRANDIFLORA ("CALIFORNIA SUNBEAMS").}

Fine type of this well-known plant, flowers measuring nearly four inches in diameter; blooms very early.

Price, per facket, 25 cents.

\section{NEW EARLY FLOWERING COSMOS "DAWN."}

A beautiful dwarf compact growing variety, flowering from July until frost. The large white flowers are delicately tinged with pink. Price, per packet, 15 cents.

\section{COSMOS TINTS OF "DAWN."}

The flowers have a white ground, finely flecked or flushed with a delicate pink. They are variously formed and very beautiful. Price, per packet, 15 cents.

\section{COSMOS NEW MARGUERITE.}

The flowers, which are laciniated or fringed, resemble Marguerites but are much more beautiful. They range in color from pure white to dark red. Price, per packet, 1 ๖̌ cents.

\section{COSMOS IMPROVED YELLOW.}

Flowers a beautiful yellow, about three inches in diameter, blooming when very young.

Price, per packet, 15 cents.

\section{COSMOS SINGLE DAHLIA FLOWERED "CRIMSON."}

Splendid flowers of the richest shades of crimson, very large and resembling single Dahlias in shape.

Price, per packet, 15 cents.

The Five New Cosmos, a packet of each for 60 cents. 


\section{CACTUS DAHLIA CONSTANCIA.}

Flowers beautiful pure white, borne in great profusion, fine for cutting. Price, per packet, 25 cents.

\section{NEW CACTUS DAHLIA MONARCH.}

Immense flowers, with very broad folded petals; color, deep dark velvet red, with mossy yellow centre.

Price, per packet, 25 cents.

\section{ESCHSCHOLTZIA (THE GOLDEN WEST).}

Flowers mottled yellow, measuring two inches across. Especially adapted to the Eastern climate, owing to their early and long continued season of blooming. Price, per packet, 50 cents.

\section{GAILLARDIA, JAMES KELWAY.}

A beautiful giant flowering variety, with grand flowers five to six inches in diameter; bright scarlet with a gold margin and fringed edges. Hardy perennial. Price, 25 cents per packet.

\section{NEW FRINGED MAMMOTH HOLLYHOCK ("ALLEGHENY").}

One of the grandest novelties sent out this year. The flowers, which measure five to seven inches across, are beautifully fringed, and are borne in great profusion. Price, per packet, 25 cents.

\section{MYOSOTIS PALUSTRIS (TOM THUMB),}

This lovely novelty is a pygmy form of the well known Forget-Me-Not. The plants form little tufts, and produce great numbers of flowers. Price, per packet, 35 cents.

\section{PAPAVER CARDINALE HYBRIDS.}

In separáte colors. Dark green, deeply laciniated foliage and compact habit characterize the type. Bright Rose, Copper Rose, Chamois, Brick Red. Per packet, 25 cents.

\section{POPPIES (NEW FAYAL).}

The flowers are very beautiful, running in all shades of red, pink, maroon and white; double and single.

Per packet, 25 cents.

\section{PRIMULA OBCONICA GRANDIFLORA HYBRIDA.}

A fine form of this well-known plant, much improved. Price, per packet, 25 cents.

TORENIA FOURNIERI SPECIOSA (PRINCESS HELEN OF MONTENEGRO).

A fine new giant form. China blue, spotted with indigo blue. Very beautiful. Price, per packet, 35 cents.

\section{TORENIA FOURNIERI SPECIOSA (THE BRIDE).}

Very beautiful. The over-lip is white, the under-lip and side flaps are a beautiful delicate pink, while the bottom of the corolla is golden yellow. Per packet, 50 cents.

\section{ZINNIA DOUBLE GIANT (QUEEN VICTORIA).}

The flowers are pure white, very double, and measure nearly four inches across. Very fine.

Per packet, 25 cents. 


\title{
NEW HYBRID WICHURIANA ROSES,
}

\author{
OR THE
}

\section{DOUBLE MEMORIAL ROSE.}

$I^{T}$ gives me great pleasure to offer to the public the first Hybrids of Rosa Wichuriana, which are the grandest novelty of 1898 . The habit of these new Roses is the same as the Rose Wichuriana, or Memorial Rose. The growth is creeping, and therefore can be used to cover the ground, stems of trees, pillars, posts, trellises, or any other purpose desired, including pot culture. They are the hardiest Roses I know of, and will stand any climate or exposure. They thrive well in the poorest soil or on a gravel bank. The foliage is finely cut, thick, of a leathery substance, bright green, shining as if varnished, not subject to mildew or any insect, but keeps its full beauty until almost Christmas. The flowers are produced in the greatest profusion, so that a two or three year old plant will produce several thousand most exquisite biossoms, which are deliciously fragrant and last a long time in perfection.

\section{MANDA'S TRIUMPH (:Tanda).}

This grand Rose is of free growth, luxuriant foliage, and produces large clusters of double pure white flowers, two inches in diameter, beautifully imbricated and well formed, very sweet scented.

\section{UNIVERSAL FAVORITE (Manda).}

This is the most vigorous plant of the set. The long branching shoots are covered with dense bright green foliage. The double flowers are over two inches in diameter, and of a beautiful rose color, similar to the Bridesmaid, and deliciously fragrant. A grand variety for any purpose.

\section{SOUTH ORANGE PERFECTION (Manda).}

This is a gem, growing freely close to the ground, and having multitudes of the most perfectly formed double flowers, about one and a half inches in diameter, soft plush pink at the tips, changing to white. It lasts a long time in perfection.

\section{PINK ROAMER (Manda).}

This is without question a Hybrid between the Sweetbrier, and carries these characteristics in bloom, while the growth, which is very rampant, and the luxuriant foliage, partake more of the Wichuriana. The single flowers, which are produced in closed heads, are nearly two inches in diameter, bright rich pink, with almost a white centre, which lightens up the orange-red stamens, producing an effect which, combined with fragrance, makes it one of the most valuable roses in cultivation.

Taking them together, the set of the four above varieties should be in every garden, and I am sure they will prove more valuable than the celebrated Crimson Rambler, as they are of a much more vigorous growth. Some shoots made last season were from fifteen to twenty feet in length, which is marvelous amongst roses.

These roses have proven everything that has been claimed for them the last season, and are in great demand on account of their many qualities.

Price, 2-inch pots, 25c. each; \$2.50 per dozen; \$18 per hundred. Price, extra strong, 1-year field.grown plants, at 75c. each; $\$ 7.50$ per dozen. Few extra strong 2-year old specimenr, at \$3.75 each.

Colored plate of these Roses, with Press comments, will be sent on application. 


\section{TESTED NEW CANNAS OF 1897.}

I am very pleased to offer such a grand lot of new varieties of this very popular plant for outdoor bedding; in fact, no garden should be without this collection of five sterling kinds.

CANNA, MANDA'S IDEAL.-(Manda.)

To my mind the finest and most useful Canna in cultivation. Naturally, it grows from two to three feet high, having small glaucous greer leaves, and producing stout stems, which branch and throw up as many as a dozen large trusses of well formed flowers, which are of a rich scarlet vermilion color. It lasts for a long time in perfection, and the numerous spikes fully developed give it a dazzling appearance. A like effect is not produced by any other Canna in cultivation. I raised this Canna from seed three years ago, and have fully tested its merits from that time, and feel confident that it will be cne of the best acquisitions for bedding purposes. Ready for delivery after March rst. Price, 25 cents each ; $\$ 2.50$ per dozen.

\section{CANNA, ROBERT CHRISTY.-(Manda.)}

A beautiful acquisition in its color, was raised by Mr. Robert Christy, of Newport, R. I., and has captivated everybody who has seen it. Grows about four feet high, with stout stem supporting large musa-like foliage, and producing immense spikes of bright orange vermilion flowers, which is a shade unique amongst Cannas. Awarded First-Class Certificate by the New York Florists' Club. Ready after March rst. Price, 25 cents each; $\$ 2.50$ per dozen.

\section{CANNA, JOHN WHITE.-(White.)}

This is a distinct novelty in the way of Cannas, growing about three feet in height, with reddish stems, light green foliage, beautifully striped with white, yellow and rose, edged with red, the combination of which produces a grand effect, and on account of which it will be valuable for subtropical borders and beds, and for other purpose., where fine foliage plants are in demand. The flowers are small and of a bright red color, succeeded by red fruit, which enhances its appearance. Ready after March Ist. Price, 25 cents each; \$2.50 per dozen.

\section{CANNA, ITALIA.}

One of the wonders of recent introduction, growing from six to nine feet high, with large musa-like foliage. The flower spikes produce a number of extraordinary large flowers of a beautiful scarlet color, edged with yellow, a plant that should be in every collection. Price, 25 cents each; $\$ 2.50$ per dozen.

CANNA, AUSTRIA.

A companion to the above-named variety, having the same wonderful qualities of growth and flowers, with the exception that its wonderful large blooms are of a beautiful canary yellow, faintly spotted with purple. Price, 25 each ; \$2.50 per dozen.

Collection of the Five New Cannas, one of each, for $\$ 1.00$.

\section{NEW HARDY PLANTS.}

\section{RUDBECKIA LACINIATA Fl. PI. ("GOLDEN GLOW").}

Offered for the first time last year. A hardy perennial plant growing eight feet high, branching freely, and bearing by the hundreds, on long, graceful stems, exquisite double blossoms of the brightest golden color and as large as Cactus Dahlias. Strong plants, 15 cents each; $\$ 1.50$ per dozen.

\section{RAMBLER ROSES.}

Every one knows the Crimson Rambler. Since its introduction other colors of this valuable rose have been imported, so that I can offer now the following: The Crimson Rambler, The White Rambler, The Pink Rambler, The Yellow Rambler. Strong flowering plants, 35 cents each; $\$ 3.50$ per dozen; or, one of each four varieties, \$1.00. 


\section{NEW PHLOX PANICULATA, "TOM THUMB."}

This novelty is quite a distinct departure from this section, as it grows only six to ten inches in height, and on that account will be found very useful for bedding, for edging of beds, or borders. The white flowers are freely produced during the whole summer, covering the plant like a mound of snow. The most desirable hardy novelty for 1898 . Price of plants, 25 cents each $; \$ 2.50$ per dozen.

\section{NEW BULBS.}

\section{NEW GOLDEN YELLOW CALLAS.}

Calla Pentlandii (True.)-Grand novelty, with fine green foliage and extra large spathes of beautiful yellow color. Rare, $\$ 4.50$ each.

Calla Elliottiana.-One of the most remarkable plants of recent introduction. Foliage large, beautifully marked with white. Flower spathes very large, of a fine, clear yellow color, a plant that should be in every collection. Rare, $\$ 4.50$ each.

New Fancy Leaved Caladiums. - I was fortunate to obtain from South America a grand collection of these beautiful plants, with the most exquisite foliage imaginable. I will select you six most distinct and most beautiful types for $\mathbf{\$ 5 . 0 0}$, or twelve of the finest for $\mathbf{\$ 1 0 . 0 0}$.

\section{ABUTILON SAVITSI.}

This is a grand novelty, and a very decided improvement on Souv. de Bonn. The leaves are heavily marked with a pure silvery white. The variegations are exceedingly beautiful, making it a fine decorative plant. There is no Abutilon that can compare with it for striking beauty. 35 cents each; $\$ \mathbf{8 3 . 5 0}$ per dozen.

\section{NEW CRYSANTHEMUMS.}

ALICE F. CAREY.

Fine reflexed pink, good foliage and stem, excellent keeper. Price, 40 cents each ; $\$ 3.50$ per dozen.

\section{WM. H. CHADWICK.}

An immense incurved bloom, waxy white tinted pink, fine stem and foliage extra.

\section{ROB'T G. CAREY.}

Price, $\$ 1.00$ each ; $\$ 6.00$ per dozen.

Incurved white of good form, good substance and excellent keeper. Price, 40 cents each; $\$ 3.50$ per dozen.

\section{CHEMPWEE.}

Clear, bright yellow sport from Silver Cloud, large flower, fine stem and foliage.

\section{DOLORES.}

Price, 40 cents each; $\$ 3.50$ per dozen.

Large incurved deep yellow, with broad petals, fine stem and foliage.

\section{FRANK HARDY.}

Price, 40 cents each ; $\$ 3.50$ per dozen.

Incurved Japanese white flower of extraordinary depth. Fine stem and foliage. Considered the best new Chrysanthemum for 1898 . I have strong plants of this variety.

Price, 50 cents each ; $\$ 3.00$ per dozen; $\$ 20.00$ per 100 .

\section{MINNEW ASKA.}

Deep pink bold globular flower, straight and strap petals, stem and foliage good. Price, 40c. each ; \$3.50 doz. MERRY CHRISTMAS.

Very late, a fine, white, well formed, full centre, good for Christmas cutting.

Price, 35 cents each; $\$ 3.00$ per dozen. 


\section{MRS. C. H. PEIRCE.}

Soft, deep yellow, large globular flower, with fine stem and heavy foliage. Price, 35 cts. each; \$3.50 dozen.

\section{MADELEINE PRATT.}

Fine, high, blooms very vigorous; pure white. Price, 35 cents each; $\$ 5.00$ per dozen.

\section{PENNSYLVANIA.}

Sport from Philadelphia. Beautiful primrose, yellow; one of the finest for commercial or exhibition purposes. Price, 50 cents each ; $\$ 5.00$ per dozen.

\section{SPOTSW00D.}

Light yellow, deep, fine formed flower, on the style of Bonnaffon; excellent. Price, 40 cts. each; \$3.50 doz.

\section{SNOW QUEEN.}

Large, nicely finished, rounded white flower, fine stem and foliage. Price, 50c. each ; \$5.00 per dozen.

\section{MISS GLADYS VANDERBILT.}

Pearl white, with lemon shaded centre, a fine sort for commercial or exhibition purposes.

\section{THE YELLOW FELLOW.}

Price, 50c. each ; $\$ 3.50$ per dozen.

Rich bright yellow; fine robust grower; fine for exhibition as pot plant. Price, 50c. each ; \$3.00 per dozen.

\section{T. H. SPAULDING.}

Beautiful and distinct variety, with large incurved flower of rich, deep, wine color.

Price, 35c. each; $\$ 3.50$ per dozen. One of each of the 16 varieties for $\$ 7.50$.

All the leading Chrysanthemums at popular prices.

\section{NEW CARNATIONS.}

BON TON.

Bright. warm scarlet; very robust habit; large flower, strong stem.

\section{MRS. JAMES DEAN.}

Clear, silvery pink; vigorous habit; large flower. Price, $\$ 2.00$ per dozen ; $\$ 10.00$ per hundred.

\section{GOLD NUGGET.}

Clear, deep yellow, slightly marked with red; large flower; strong stems; vigorous.

\section{NEW YORK.}

Price, $\$ 2.00$ per dozen ; $\$ 10.00$ per hundred.

Bright, cerise pink; strong, vigorous habit; large flower; constant bloomer.

Price, $\$ 2.00$ per dozen ; $\$ 10.00$ per hundred.

\section{CARNATION WHITE CLOUD.}

Strong, vigorous grower, with large, fragrant white flowers, produced on long strong stems.

Price, $\$ 2.00$ per dozen; $\$ 10.00$ per hundred.

\section{CARNATION WELLESLEY.}

Beautiful bright red flower, the finest red to date. Price, $\$ 2.00$ per dozen; $\$ 10.00$ per hundred.

\section{CARNATION JOHN YOUNG.}

Deeply fringed white flowers; strong grower, free bloomer. Price, $\$ 2.00$ per dozen ; $\$ 10.00$ per hundred. 
EVELINA.

Flowers large, pure white, strong calyx, fragrant, free and healthy grower.

\section{EMPRESS.}

Price, $\$ 2.00$ per dozen; $\$ 10.00$ per handred.

Bright, rich crimson base of petals, fiery scarlet, very large, fringed and fragrant.

\section{JACK FROST.}

Price, $\$ 2.00$ per dozen; $\$ 10.00$ per hundred.

Enormous white flowers of fine form, and fragrant, good habit and free growth.

Price, $\$ 2.00$ per dozen; $\$ 10.00$ per hundred.

Dozen of each of the ten varieties for $\$ 14.00$.

All the leading sorts of Carnation supplied at popular prices.

\section{ORCHID MATERIAL.}

To grow Orchids successfully, good material is essential, and therefore I offer to my customers specially selected peat and moss, such as I use for my Orchids, also my new Orchid Baskets.

\section{ORCHID PEAT.}

Collected from high lands, and thus keep fresh and sweet for a long time. Price, as collected, $\$ 2.75$ per bbl. Price for picked, ready to use, $\$ 4.50$ per bbl.

\section{SPHAGNUM MOSS.}

Nice fresh-gathered thick-headed variety, as collected, \$2.75 per bbl. Picked over, ready for use, $\$ 4.50$ per bbl.

\section{MANDA'S NEW ROUND ORCHID BASKET.}

I cannot recommend too highly this improved Orchid Basket, not only for Orchids, but for Aroids, Bromeliads, and similar plants. Being round, they can be used for hanging pot plants of every description. They are made of best hardwood, put together with copper wire, which makes them durable, useful and ornamental. Doz. price, 5-inch, \$2.00; 6-inch, \$2.25; 7-inch, \$3.00; 8-inch, \$3.50; 10-inch, \$t.50; 12-inch, \$õ.00 per doz.

Order a sample lot and you will never use others.

The best Insecticide for all purposes, = = =

$\$ 1.50 \begin{gathered}\text { Per } \\ \text { Bottle. }\end{gathered}$

Which is extract from $200 \mathrm{lb}$. of tobacco.

\section{IMPORT DIRECT FROM}

AFRICA, AUSTRALIA, BELGIUM, BERMUDA, CENTRAL AMERICA, ENGLAND, EAST INDIES, GERMANY, HOLLAND, JAPAN, SOUTH OF FRANCE, SOUTH AMERICA, WEST INDIES.

\section{SEEDS, PLANTS AND BULBS, OF ALL DEscriprons, IN LARGE QUANTITIES.}

If you are interested in any of the above, send me your name, and I will place same on a Special List, and notify you of every Importation, with Special Low Quotation.

EXPECTED IMPORTATION NOW: PALM SEEDS and ORCHIDS. 